Abstracta Iranica Abstracta Iranica

Revue bibliographique pour le domaine irano-aryen

Volume 25 | 2004

Comptes rendus des publications de 2002

\title{
"Some Further Thoughts on the Bisitun Monument and the Genesis of the Old Persian Cuneiform Script ». BAI 13, (1999 [2002]), pp. 45-66.
}

\section{Rémy Boucharlat}

\section{(2) OpenEdition}

Journals

Édition électronique

URL : http://journals.openedition.org/abstractairanica/4267

DOI : 10.4000/abstractairanica.4267

ISSN : 1961-960X

Éditeur :

CNRS (UMR 7528 Mondes iraniens et indiens), Éditions de l'IFRI

Édition imprimée

Date de publication : 15 mai 2004

ISSN : 0240-8910

Référence électronique

Rémy Boucharlat, " «Some Further Thoughts on the Bisitun Monument and the Genesis of the Old Persian Cuneiform Script ». BAl 13, (1999 [2002]), pp. 45-66. », Abstracta Iranica [En ligne], Volume 25 | 2004, document 66, mis en ligne le 15 mars 2006, consulté le 25 septembre 2020. URL : http:// journals.openedition.org/abstractairanica/4267 ; DOI : https://doi.org/10.4000/abstractairanica.4267

Ce document a été généré automatiquement le 25 septembre 2020.

Tous droits réservés 
«Some Further Thoughts on the Bisitun Monument and the Genesis of the Old Persian Cuneiform Script ». BAI 13, (1999 [2002]), pp. 45-66.

\section{Rémy Boucharlat}

Ce paragraphe de l'inscription de Darius à Bisutun (DB \$70) n'a pas fini de susciter des hypothèses. L'A. conclut que la seconde version élamite qui dit que l'inscription voisine a été faite pour la première fois en aryen (vieux perse) n'est pas la preuve définitive que l'écriture vieux-perse a été inventée à cette occasion. C'est pourtant à cette hypothèse que se rallie $\mathrm{Ph}$. H. qui ne voit pas quelles inscriptions VP pourraient être antérieures à Bisutun; certainement pas celles de Pasargades qui, même si elles mentionnent Cyrus, doivent être du temps de Darius. Avec la reconstitution minutieuse des étapes de la fabrication de Bisutun, bas-relief et inscriptions, ces pages constituent une belle mise au point sur ce monument fondateur du pouvoir de Darius.

\section{INDEX}

Thèmes : 3.2.2. Pré-Achéménides et Achéménides 
AUTEURS

RÉMY BOUCHARLAT

CNRS - Lyon 